\title{
Emerging from Anonymity: The First Generation of Writers of Songs and Drama in Mid-Ming Nanjing*
}

\author{
Tian Yuan Tan \\ (School of Oriental and African Studies)
}

\begin{abstract}
This article traces the first generation of writers of songs and drama in Nanjing who emerged from the anonymous context of early Ming court entertainment and established their name and reputation in the second half of the fifteenth century. These writers-Shi Zhong (1437-after 1516), Chen Duo (1454?-1507?), and Xu Lin (14621538)_represented a different mode of writing songs and drama. For them it was no longer a professional occupation, as in the case of the court performers, but became part of their cultural and social life. The extent to which our knowledge of these firstgeneration $q u$ writers depends on local sources and on acts of remembrance by later Nanjing authors is also examined.
\end{abstract}

\section{Résumé}

Cet article s'intéresse à la première génération d'auteurs d'airs à chanter et de pièces de théâtre ayant émergé à Nankin de l'anonymat des divertissements de cour du début des Ming; ces auteurs — Shi Zhong (1437-après 1516), Chen Duo (1454?-1507?), et $\mathrm{Xu}$ Lin (1462-1538) — se sont fait un nom pendant la seconde moitié du Xve siècle. Ils sont représentatifs d'une manière différente de composer chansons et pièces de théâtre: il ne s'agissait plus pour eux d'exercer un métier, comme dans le cas des artistes de cour, mais de se consacrer à une occupation intégrée à leurs activités culturelles et sociales. L'article examine également à quel degré notre connaissance de ces auteurs de $q u$ de la première génération est tributaire des sources locales et des

* A portion of this essay was presented at the 17th Biennial Conference of the European Association for Chinese Studies held in Lund, August 6-10, 2008. I would like to thank the participants for their comments. I am also grateful to Wilt L. Idema and the anonymous reviewers for T'oung Pao for their very helpful suggestions on earlier drafts. 
efforts d'auteurs plus tardifs, également originaires de Nankin, pour restituer leur mémoire.

\section{Keywords}

Nanjing, Shi Zhong, Chen Duo, Xu Lin, songs, drama

\section{Introduction}

The Yuan dynasty (1260-1368) is often regarded as the golden age of $q u$ 曲 (literally, "songs"), a collective term that refers both to sanqu 散曲 (“dispersed" or "individual songs"—a kind of song verse in Chinese literature)—and xiqu 戲曲 (drama). A number of late-Yuan qu writers continued to be active in the early decades of the Ming dynasty (1368-1644), ${ }^{1}$ but whereas during the Yuan $q u$ thrived in commercial theaters and urban centers and appears to have been enjoyed by people of all classes, in the early Ming the genre was largely associated with the regional courts and the two capitals. For example, writers such as Tang Shi 湯式 (fl. 1383), Yang Ne 楊訥 (fl.1402), and Jia Zhongming 賈仲明 (1343-1422) enjoyed the patronage of the Yongle emperor (r. 1402-1424) when the latter was still the Prince of Yan in Beijing. ${ }^{2}$ Furthermore, the most prolific and important $q u$ writer in the first half of the fifteenth century was Zhu Youdun 朱有燉 (1379-1439), the so-named Exemplary Prince of Zhou 周憲王 enfeoffed in Kaifeng. ${ }^{3}$ The next few decades of $q u$ activity continued to be dominated by court writers and performers producing songs and drama for palace entertainment and consumption. But the early Ming was, mainly, an age of anonymous $q u$ writing in which few authors of songs and drama were known by name.

1) See, e.g., the sixteen $q u$ writers listed in Zhu Quan 朱權, Taihe zhengyin pu 太和正 音譜, in Zhongguo gudian xiqu lunzhu jicheng 中國古典戲曲論著集成 (Beijing: Zhongguo xiju chubanshe, 1959; rpt. 1980), vol. 3, 22-23.

2) See Luguibu xubian 錄鬼簿續編, in Zhongguo gudian xiqu lunzhu jicheng, vol. 2, 28384, 292. For a discussion of these three writers, see Wilt L. Idema, The Dramatic Oeuvre of Chu Yu-tun (1379-1439) (Leiden: E.J. Brill, 1985), 210-33. See also Zhao Yishan 趙義山, “Lun chengqian qihou de zhongyao qujia Tang Shi” 論承前啓後的重要曲家 湯式, Sichuan daxue xuebao (zhexue shehui kexue ban) 2004.4: 69-73.

3) For studies of Zhu Youdun, see Idema, Dramatic Oeuvre of Chu Yu-tun, and Wang Xuefeng 王學鋒, “Jin bainian Zhu Youdun yanjiu shulun” 近百年朱有燉研究述論, Xiqu yishu 28.1 (2007): 34-41. 
It was not until the second half of the fifteenth century that a new generation of $q u$ writers broke through this anonymity. Interestingly, their emergence in the mid-Ming took place as a distinctly local phenomenon-for example, in Suzhou with such writers as Zhu Yunming 祝允明 (1460-1526) and Tang Yin 唐寅 (1470-1523), in Shaanxi with Wang Jiusi 王九思 (1468-1551) and Kang Hai 康海 (1475-1541), in Shandong with Li Kaixian 李開先 (1502-1568), ${ }^{4}$ and in Yunnan with Yang Shen 楊慎 (1488-1559).

This essay focuses on another major center of $q u$ writing, Nanjing, which is unique in comparison with the other local centers. On one hand, Nanjing was the secondary capital of the Ming and home to the court entertainment bureau, thus the center of anonymous $q u$ writing for palace consumption. But it was also a major center of literary culture which produced and gathered burgeoning writers and artists. This is why it presents us with a perfect case to examine the transition from the anonymous world of $q u$ writing in the early Ming courts to the emergence of authors of songs and drama in the mid-Ming. In what follows I will trace the first generation of $q u$ writers who appeared in Nanjing in the mid-Ming, most of whom have been little studied before, or not at all, keeping the following questions in mind: Who were these writers who were the first to gain a reputation on the literary scene of mid-Ming Nanjing for their $q u$ writings? What did they write, and in what style? Why did they emerge during this period? And finally, what sources allow us to learn about them?

\section{Anonymous Songs and Drama for Court Entertainment in Early-Ming Nanjing}

As the early capital of the Ming dynasty and a major city, Nanjing was by no means short of activities related to songs and drama. ${ }^{5}$ The city

4) For a study of Wang Jiusi, Kang Hai, and Li Kaixian, and the two local $q u$ communities formed around them in Shaanxi and Shandong respectively, see Tian Yuan Tan, Songs of Contentment and Transgression: Discharged Officials and Literati Communities in SixteenthCentury North China (Cambridge, Mass.: Harvard Univ. Asia Center, 2010, in press).

5) For studies on Nanjing as a city and as the early Ming capital, see Frederick W. Mote, "The Transformation of Nanking, 1350-1400," in The City in Late Imperial China, ed. G. William Skinner (Stanford: Stanford Univ. Press, 1977), 101-53, and Edward L. Farmer, Early Ming Government: The Evolution of Dual Capitals (Cambridge, Mass.: Harvard 
housed the Court Entertainment Bureau (jiaofangsi 教坊司), which was in charge of songs and drama for court performances and was maintained in Nanjing after the shift of the capital to Beijing in $1421 .{ }^{6}$ In addition to that, sixteen state-operated winehouses were established in Nanjing, where singsong girls performed for and entertained officials. The Hongwu government also built the Fuleyuan 富樂院 (Court of Abundant Pleasures), which, apart from being a state-managed entertainment house, also provided the compound where the actors and actresses registered with the Court Entertainment Bureau were housed. ${ }^{7}$ Moreover, two imperial theaters were built in the capital, perhaps motivated by the increased number of actors and actresses in the area, and also with the expectation that the competition between the two theaters would result in higher quality of performances and in attracting larger crowds. ${ }^{8}$ Nanjing also appears to have been one of the earliest centers for the printing of drama in the Ming. For example, the early

Univ. Press, 1976). For discussions on Nanjing's special place in Chinese literary and political history, see Stephen Owen, "Place: Meditation on the Past at Chin-ling," Harvard Journal of Asiatic Studies 50 (1990): 417-57, and David B. Honey, "Before Dragons Coiled and Tiger Crouched: Early Nanjing in History and Poetry," Journal of the American Oriental Society 115 (1995): 15-25.

6) After 1421 both capitals in Beijing and Nanjing had a jiaofangsi, but the Zhonggusi 鐘鼓司 (Bell and Drum Register) in charge of inner court performances had shifted to Beijing. See Tao Muning 陶慕寧, “Ming jiaofang yanju kao” 明教坊演劇考, Nankai xuebao 1999.6: 107. For studies of the significance of the Ming dynasty jiaofangsi in comparison with such institutions in preceding dynasties, see Li Shunhua 李舜華, Liyue yu Ming qianzhongqi yanju 禮樂與明前中期演劇 (Shanghai: Shanghai guji chubanshe, 2006), 66-91, and Zhang Ying 張影, Lidai jiaofang yu yanju 歷代教坊與演劇 (Ji'nan: Qi Lu shushe, 2007), chap. 5 and 6.

7) See Wilt L. Idema, "State and Court in China: The Case of Hung-wu's Imperial Theater," Oriens Extremus 23 (1976): 180-81; Wilt L. Idema and Stephen H. West, Chinese Theater, 1100-1450: A Source Book (Wiesbaden: Franz Steiner, 1982), 108-9; Oki Yasushi 大木康, Chügoku yüri kūkan: Min Shin shinwai gijo no sekai 中国遊里空間: 明 清秦淮妓女の世界 (Tokyo: Seidosha, 2002), 50-60; Li Shunhua, Liyue yu Ming qianzhongqi yanju, 128-30. For the theatrical activities of the Court Entertainment Bureau in Nanjing, see also Tao Muning, "Ming jiaofang yanju kao," esp. 108-9, and Zhang Ying, Lidai jiaofang yu yanju, 199-209. Although Ming Taizu (r. 1368-1398) was wary of the subversive potential of the theater and did take several measures to curb its influence and control the content of the plays performed, the actual impact of his prohibitions on drama should not be overstated. See Tian Yuan Tan, "The Sovereign and the Theater: Reconsidering the Impact of Ming Taizu's Prohibitions," in Long Live the Emperor: Uses of the Ming Founder across Six Centuries of East Asian History, ed. Sarah Schneewind (Minneapolis: Society for Ming Studies, 2007), 149-69.

8) Idema, "State and Court in China," 182. 
fifteenth-century edition of the two-zaju 雜劇 cycle Jiao Hong ji 嬌紅 記 (The story of Jiaoniang and Feihong) was published by the Nanjing printing house Jidetang 積德堂 (Hall of Accumulated Virtues) in $1435 .^{9}$

The existence of these establishments and institutions suggests that Nanjing in the early Ming was a major center for the performance and printing of songs and drama. For a city so affluent in $q u$-related activities, one might assume that a list of local writers involved in $q u$ writing from the start of the Ming dynasty could be readily established. Yet this is not the case: we in fact do not know many named Nanjing writers associated with $q u$, at least not for the first century of the dynasty. The nature of $q u$ writing for court entertainment in the early Ming might account for this phenomenon. Songs and drama for this purpose were undertaken by professional court performers who in most cases remained anonymous. This is supported by the fact that $q u$ anthologies such as the Shengshi xinsheng 盛世新聲 (New tunes from a prosperous age, 1517 preface), which were probably compiled with a court audience in mind, do not list the names of the authors whose arias and songs are anthologized. ${ }^{10}$ Likewise, named authors are extremely rare in discussions of $q u$ writing during this period. For example, there is one record about a certain Wang Di 王迪, a clerk in the Fuleyuan who was known to be well versed in music and could

\footnotetext{
9) Famous printing houses in Nanjing such as the Fuchuntang 富春堂 and Jizhizhai 繼志齋, however, were only established during the Wanli period (1573-1620). See Yu Weimin 俞為民, “Mingdai Nanjing shufang kanke xiqu kaoshu” 明代南京書坊刊刻戲 曲考述, Yishu baijia 1997.4: 43-50, and Sun Chongtao 孫崇濤, “Zhongguo xiqu kejia shulüe” 中國戲曲刻家述略, Xiqu yishu 26.2 (2005): 61-64. Nanjing was also a center for the publishing of fiction in the latter half of the Ming dynasty. See Wang Yan'gang 汪燕 崗, “Mingdai zhongwanqi Nanjing shufang he tongsu xiaoshuo” 明代中晚期南京書坊 和通俗小説, Nanjing shehui kexue 2004.10: 55-59. For general studies of printing in Nanjing, see Zhang Xiumin 張秀民, “Mingdai Nanjing de yinshu” 明代南京的印書, Wenwu 1980.11: 78-83, and Lucille Chia, "Of Three Mountains Street: The Commercial Publishers of Ming Nanjing," in Printing and Book Culture in Late Imperial China, ed. Cynthia Brokaw and Kai-wing Chow (Berkeley: Univ. of California Press, 2005), 107-51. 10) The Shengshi xinsheng was reprinted in 1596 by the Inner Court in the imperial palace, probably to meet a high demand from court entertainers who frequently turned to this anthology for songs and arias to perform. See Wang Gang 王鋼 and Wang Yongkuan 王永寬, “Shengshixinsheng yu Zang Xian”《盛世新聲》與藏賢, Wenxue yichan 1991.4: 97.
} 
write songs and plays, but even in that case we do not know what exactly he produced. ${ }^{11}$

For songs and drama composed in Nanjing and with known authorship $^{12}$ we have to wait until the second half of the fifteenth century. This is not to suggest that no $q u$ authors are known before this period. As we shall see, at least one or two of them can be mentioned. Yet it is not until the second half of the fifteenth century that we can speak of a generation of Nanjing authors who engaged in $q u$ writing together and corresponded with each other, and whose writings and activities came to be remembered by others and have been passed down to us.

\section{Tracing the First Generation of $Q u$ Writers in Nanjing}

In his account of the significant $q u$ writers hailing from the various regions of the Ming empire, the late Ming dramatist and critic Wang Jide 王䮭德 (1542?-1623) noted five authors from Nanjing, namely Chen Yi 陳沂 (1469-1538), Hu Rujia 胡汝嘉 (jinshi 1553), Xu Lin 徐霖 (1462-1538), Chen Duo 陳鐸 (1454?-1507?), and Jin Luan 金 鑾 (ca. 1486-ca. 1575). While the first three excelled in northern songs, the last two mastered the southern tunes. Wang Jide's list gives some indication of the tradition of $q u$ writing in Nanjing, but it is far from providing a complete picture. For an in-depth study of the world of songs and drama in Ming Nanjing, we need to turn to more "local" publications.

A valuable source for this purpose is Jinling suoshi 金陵瑣事 (Trivial accounts from Jinling, hereafter JLSS), a collection of jottings in the tradition of biji 筆記 that records the lives and events in Nanjing. In the second juan, the author, Zhou Hui 周暉 (fl. 1610), turns his attention to the cultural legacy of Jinling, recounting the important figures in such fields as calligraphy, painting, $q u$, and shi poetry. In many ways this reads like a mapping of the literary field and a sort of Who's Who of the cultural world of Ming Nanjing. The section on

11) See Liu Chen 劉辰, Guochu shiji 國初事蹟, in Jinhua congshu 金華叢書 (Tuibuzhai 退補齋 edition, 1869 preface), 21a/b. This account is also included in Gu Qiyuan 顧起元, Kezuo zhuiyu 客座贅語 (Beijing: Zhonghua shuju, 1987), 188-89.

12) It is important to note that "known authorship" does not imply that authorship is certain and without dispute. 
$q u$, entitled “Qupin” 曲品 (A grading of $q u$ ), is, to my knowledge, the best source to gain access to the world of songs and drama in the Ming southern capital. It lists a total of twenty $q u$ writers, presented in rough chronological order through the first decade of the seventeenth century, when JLSS was written. ${ }^{13}$ Thus, it can be regarded as a sort of "lineage" of Nanjing $q u$ writers featuring the successive generations.

The full list of writers would be too long to discuss in its entirety. For the purpose of this essay, let me focus on the first five entries on the list, ${ }^{14}$ which read:

(1) Ma Jun's [dates unknown] xiaoling songs were no inferior to [those of] Yuan writers.

(2) Shi “The Fool” [Shi Zhong 史忠, 1437-after 1516] excelled in xiaoling.

(3) Chen Quan [dates unknown] was a xiucai [government student]. A collection of his songs (yuefu) in one juan has been published. He did not possess any profound learning as a songwriter. He was only good at ridicule and mocking.

(4) Chen Duo's Qiubi yuefu, Liyun ji'ao, and Gongyu manxing have been published. The stanza beginning with the line "Thrice playing with the plum blossoms" 15 in [the song suite] "About Boudoir Sentiments"16 can be regarded as the work of a master. His song suites are steady and harmonious, smooth

13) Zhou Hui, Jinling suoshi (JLSS) (Beijing: Wenxue guji kanxingshe, 1955), 2.110a-112b. It is noteworthy that this list is partially repeated (from the sixteenth to the twentieth writer) in Gu Qiyuan's 1618 Kezuo zhuiyu under the entry “ciqu” 詞曲; see Gu, Kezuo zhuiyu, 284. Gu also imitated Zhou's format and added another late Ming writer, Chen Suowen 陳所聞. Later, the list was further updated by the modern Chinese scholar $\mathrm{Lu}$ Qian 盧前 (1904-1950). See Lu Qian, Lunqu jueju 論曲絕句, in Lu Qian quxue sizhong 盧前曲學四種 (Beijing: Zhonghua shuju, 2006), 250-51. Such acts of remembrance by later writers updating the tradition constitute an interesting phenomenon to which I will return in the final section.

14) The sixth, Chen Yi 陳沂 (1469-1538), was acquainted with the fifth-Xu Lin—and was himself the author of a play and a song suite, but he does not appear to have been involved in $q u$ writing in association with Xu. For this reason I do not include him in this study. For the sake of clarity I have numbered the entries in the order in which they appear in the original source.

15) This is also the title of a popular Chinese tune.

16) For the full song suite, see Xie Boyang 謝伯陽, ed., Quan Ming sanqu 全明散曲 (hereafter QMSQ) (Ji'nan: Qi Lu shushe, 1993), 587-88. This song suite is entitled "Guiqing” 閨情 in the Ming manuscript edition of Chen's songs as well as in two popular qu anthologies, the Cilin zhaiyan 詞林摘䶣 and Qunyin leixuan 群音類選; but its title is “Donggui yuanbie” 冬閨怨別 in another anthology, the Beigong ciji 北宮詞紀. See QMSQ, 711, n. 226. This citation by Zhou Hui in JLSS gives us a clue about the editions through which one could read about Chen's songs in the early seventeenth century. I discuss the various editions of Chen's songs in the section devoted to him below. 
and beautiful. When musical instruments are added and they are examined against the musical rules, they are always perfect and do not miss by even the narrowest margin.

(5) $\mathrm{Xu}$ Lin in his younger days frequented the entertainment quarters. The northern and southern songs he wrote demonstrated great talent, and every single word matched the music. All the courtesans held his songs in high regard. Wen Zhengzhong [Wen Zhengming 文徵明, 1470-1559] from the Wu region once wrote an inscription for a painting and sent it to $\mathrm{Xu}$. In it there were lines that read as follows ${ }^{17}$ : "Your songs are recently circulated at Peach Leaf Ferry ${ }^{18}$ / Your colorful brush writes all over the Xue Tao paper." ${ }^{19}$ This is indeed a truthful account! During Emperor Wuzong's [r. 1505-1521] southern journey, the performer Zang Xian [who later served as Director of the Court Entertainment Bureau] recommended Xu Lin to the emperor, and summoned him to fill in the words for new tunes. The emperor was very fond of Xu's songs. I have seen several of Xu's plays such as Xiuru [ji], Sanyuan [ji], Meihua [ji], Liuxie [ji], Zhenzhong [ji], Zhonggua [ji], and Liang tuanyuan, which have all been published.

(1) 馬俊小令不減元人。

(2) 史癡工小令。

(3) 陳全, 秀才, 有樂府一卷行于世。無詞家大學問, 但工于嘲罵而已。

（4）陳鐸有秋碧樂府、稆雲寄傲、公餘漫興行于世。《咏閏情》“三弄梅花” 一閶, 頗稱作家所為。散套穩協流麗, 被之絲竹, 審宮節羽不差毫 末。

（5）徐霖少年數遊狹斜, 所填南北詞, 大有才情, 語語入律, 娼家皆崇奉之。 吳中文徵仲題畫寄徐, 有句云: “樂府新傳桃葉渡, 彩毫遍寫薛濤侥”, 迺 實錄也。武宗南狩時, 伶人藏賢萀之于上, 令填新曲, 武宗極喜之。余 所見戲文《綉襦》、《三元》、《梅花》、《留鞋》、《枕中》、《種 瓜》、《兩團圓》數種行于世。20

The list begins with Ma Jun 馬俊, an obscure figure about whom we know very little. Most of the records of Ma as a $q u$ writer I have found are in fact quoted from the one-line account in JLSS and are therefore of no assistance in providing further information about the writer. ${ }^{21}$ In JLSS, Ma is placed before the second writer, Shi "The Fool,"

17) These are the first two lines of a quatrain by Wen. For the full quatrain, see Gu Qiyuan, Kezuo zhuiyu, 205-6.

18) Peach Leaf Ferry is a place in Nanjing where it is believed that the famous calligrapher Wang Xianzhi (344-388) once composed three songs for his concubine "Peach Leaf" as a send-off.

19) Xue Tao (770-830), the famous Tang courtesan-poet, was believed to have invented a kind of crimson-colored note-slip of a size that was especially suitable for writing poetry.

20) Zhou Hui, JLSS, 2.110a-111a. Translations are my own unless otherwise stated.

21) See, e.g., Kangxi Jiangning xianzhi 康熙江寧縣誌, j. 34, cited in Zhao Jingshen 
who was born in 1437 . Since JLSS's account of literary and cultural figures generally follows a rough chronological order, we may conclude that Ma Jun must have been active before or around the $1450 \mathrm{~s}^{22}$ Another account in JLSS featuring Ma Jun as an artist also places him before the painter Wu Cheng 吳珵 (jinshi 1469). This account states that Ma's style in landscape painting followed the tradition of the Tang and Song masters and was most "ancient and elegant" (guya 古雅). ${ }^{23}$ It also gives us the courtesy and literary name of Ma, viz. Weixiu 惟 秀 and Nexuan 訥軒, respectively.

In Ma Jun's case we have the name of a writer who could write xiaoling of a high standard. Unfortunately, none of his songs has survived and I have yet to find a record of $q u$ activity involving him with contemporary writers. In other words, extant sources suggest no more than the independent case of a writer known to have written songs in earlyMing Nanjing.

Another $q u$ author who presents a similar problem is Chen Quan 陳全, the third figure on the list. Chen's dates are open to question. The Quan Ming sanqu 全明散曲 (hereafter QMSQ) includes some of his songs in its third volume (out of five), where he is placed after writers such as Hu Rujia (jinshi 1553) and Sun Siyi 孫斯億 (15291590). An important reference work, perhaps taking the lead from QMSQ, states that Chen was born around $1530 .{ }^{24}$ This would place him at a much later date than suggested in JLSS. Unlike Ma, Chen is not mentioned in other sections of JLSS, which means that there are no further clues to his dates. ${ }^{25}$ Since the later date given in $Q M S Q$ is

趙景深 and Zhang Zengyuan 張增元, eds., Fangzhi zhulu Yuan Ming Qing qujia zhuanlüe 方志著錄元明清曲家傳略 (Beijing: Zhonghua shuju, 1987), 433. The editors add that Ma Jun was an early Ming figure according to Jinling shizheng 金陵詩徵. Unfortunately, I have yet to locate this book.

22) Another account of Ma in JLSS cites his famous poetic lines, one of which is from a poem written to a certain Wang Ding 王鼎 on the topic of Wang's retirement from office. See Zhou Hui, JLSS, 2.69a. It is uncertain whether this refers to the Wang Ding who obtained his jinshi in 1481 .

23) JLSS, 2.100b.

24) See Qi Senhua 齊森華, Chen Duo 陳多, and Ye Changhai 葉長海 eds., Zhongguo quxue da cidian 中國曲學大辭典 (Hangzhou: Zhejiang jiaoyu chubanshe, 1997), 120.

25) The only other piece of biographical information I have found so far gives Chen Quan's courtesy name as Hexi 鶴溪. See Zhuang Yifu 莊一拂, ed., Ming Qing sanqu zuojia hui$k a o$ 明清散曲作家匯考 (Hangzhou: Zhejiang guji chubanshe, 1992), 191. The source for this information is not indicated. 
not supported by any evidence, I am inclined to trust the "local" knowledge of Zhou Hui in his JLSS and take Chen Quan as an earlier writer born around the mid-fifteenth century. His extant $q u$ writings include a total of eight xiaoling songs. ${ }^{26}$ As aptly described in JLSS, the main characteristic of these is "ridicule and mocking." I will discuss later this type of songs as a major style of $q u$ composition during this period.

Apart from Ma Jun and Chen Quan, the remaining three writers in the list-Shi Zhong, Chen Duo, and Xu Lin-present us with a very different situation. For the first time we have a group of writers who were acquainted with each other and collaborated in $q u$ writing. We will see that these three individuals represent different modes of lifestyle and of $q u$ writing. Yet they all shared a common interest in $q u$, and together they formed the first generation of $q u$ writers in Nanjing. The combination and interaction of their different social milieus and modes of $q u$ writing formed the larger world of songs and drama in mid-Ming Nanjing.

\section{Shi Zhong "The Fool": An Eccentric Recluse Figure}

It was said that Shi Zhong (original name Xu Duanben 徐端本) only learned to speak at age seventeen; but though he might appear foolish, he was in fact very smart. Everybody called him the "Fool," or "Foolish Immortal" (chixian 癡仙). ${ }^{27}$ The following description in JLSS captures the unconventional image Shi portrayed:

By nature, [Shi Zhong] was outstanding and untrammeled. He loved to don a commoner's robe, wear a square rain-hat, stick flowers in his hair, ride on the back of an ox, and sing songs clapping his hands. He moved freely among the city streets and markets, as if there was no one around.

性卓榮不羈, 好披白布袍, 載方斗笠, 䰅邊插花, 坐牛背, 鼓掌謳吟。往 來市井, 旁若無人。28

There are numerous accounts of Shi Zhong in JLSS, all under a section titled “Anecdotes on Shi the Fool” (Shi chi yishi 史癡逸事), ${ }^{29}$ which 
testify to his idiosyncratic style and eccentric character. For example, there is an interesting anecdote about how upon meeting a military official who came to visit him he spontaneously boarded a boat with the latter and went off travelling without even saying a single word to his family. ${ }^{30}$

Shi Zhong's occupation and social status are uncertain. It was said that he had little regard for wealth. He was unconcerned about his livelihood, yet was very generous toward others. As a result, he lived in poverty in his later years. ${ }^{31} \mathrm{He}$ might have relied on his paintings for a livelihood, but unlike some of his contemporaries there is no evidence that he sought commissions from officials, nobility, or wealthy patrons. ${ }^{32}$

A clear representation of his spirit and eccentric character, Shi Zhong's paintings were known to be full expressions of his feelings and could not be measured using the conventional standards in art. ${ }^{33} \mathrm{He}$ indeed enjoyed a respectable reputation as an artist, and we have records of a very popular courtesan who studied painting under him during the Chenghua period (1465-1487). ${ }^{34}$

More important for the purpose of this study, Shi Zhong was also known for his talent and interests in $q u$ writing:

[Shi Zhong] was especially talented in composing songs and new tunes. Whenever he picked up a brush he wrote following his whim and without much contemplation, and he would compose fifty, sixty, or even a hundred songs before stopping. Even his contemporaries Chen Dasheng [Chen Duo] and Xu Ziren [Xu Lin], who were famous masters in writing lyrics and songs, paid homage to his quick wit and speed in composition.

30) Ibid., 3.158b. One may compare this to a similar account in Shishuo xinyu 世說新語 about Zhang Han 張翰 going off with a man in his boat without informing his family. See Yu Jiaxi 余嘉錫, ed. and comm., Shishuo xinyu jianshu 世說新語箋疏 (Shanghai: Shanghai guji chubanshe, 1993), 23.739-40.

31) JLSS, 3.159a.

32) Stephen Lee Little, "Du Jin, Tao Cheng, and Shi Zhong: Three Scholar-Professional Painters of the Early Ming Dynasty" (Ph.D. diss., Yale University, 1987), 210.

33) JLSS, 2.101b and 2.157b.

34) Ibid., 2.132a. For studies on Shi Zhong's role as an artist and on his paintings, see James Cahill, Parting at the Shore: Chinese Paintings of the Early and Middle Ming Dynasty, 1368-1580 (New York: Weatherhill, 1978), 139-40, 153; Little, "Du Jin, Tao Cheng, and Shi Zhong," 205-22. 
才情長於樂府新聲。每搦筆乘興書之, 略不構思, 或五六十曲, 或百曲, 方閣筆。同時陳大聲、徐子仁, 皆以詞曲名家, 亦服其敏速。35

Though we are told that Shi could easily write a hundred songs in one sitting, only nineteen of his xiaoling songs have been preserved. ${ }^{36}$ Among them we find a set of ten songs titled "Shuhuai zishi" 述懷 自適 (Expressing my sentiments in enjoying my life). Here is the first of them:

To the tune of Putianle 普天樂 under the Northern Zhonglü 中呂 mode:

Tower of the Reclining Fool,

A realm of perfected immortals!

[Here,] one does not pursue power and wealth,

One does not yearn for empty fame.

The spring breeze does not carry the affairs of the mundane world,

Before our eyes, what a clear and peaceful sight!

Outside the window, mountain scenery adds to the inspiration for poetry;

When guests visit we celebrate this peaceful age together.

[With us are] a poem-sack, a wine gourd,

An elixir furnace, a tea-stove,

A qin handbook and a chessboard.
臥癡樓,

真仙境。

不趨勢利,

不尚虛名。

東風不世情，

眼底多清淨。

窗外山光添詩興，

客來時共樂昇平。

詩囊酒漂,

藥爐茶䆮,

琴譜碁枰。37

The songs emphasize the joy of Shi Zhong living as a recluse. Just like the one cited above, each is centered on and begins with the locale of his reclusion, the "Tower of the Reclining Fool," named after himself. Although Shi often portrayed himself as a recluse figure, he was by no means a hermit: he was actually rather well connected to the cultural world of his times. The famous artist Wu Wei 吳偉 (1459-1508), better known by his sobriquet Xiaoxian 小仙 (Little Immortal), once painted a portrait for Shi Zhong which won high praise by another

\footnotetext{
35) JLSS, 2.132a.

36) QMSQ, 410-15. It is interesting to note that all, except one, of his xiaoling are preserved only in the Ming anthology Yuefu qunzhu 樂府珜珠. (The one exception is preserved in an inscription on a painting I will discuss later.)

37) $Q M S Q, 410$.
} 
Ming master, Shen Zhou 沈周 (1427-1509). ${ }^{38}$ In 1504, Yang Xunji 楊循吉 (1458-1546) also wrote a biography for Shi Zhong. ${ }^{39}$

To attempt to summarize Shi's style of songs is perhaps unwise, given that now we have access to only nineteen songs by a writer known to be capable of composing, and who probably did write, hundreds of songs. What one can derive from his extant songs is that reclusion seems to have been one of his favorite themes in $q u$ writing. ${ }^{40}$

Most of Shi Zhong's songs appear to have been written and performed within the immediate context of his family. His concubine $\mathrm{He}$ Yuxian 何玉仙, nicknamed “White Clouds" (Baiyun 白雲), was gifted with a good understanding of music. Shi Zhong therefore hired Zhang $\mathrm{Lu}$ 張祿, a pipa master well-known in both capitals, to teach her how to play pipa. After White Clouds had fully mastered Zhang's marvelous skills, whenever Shi Zhong wrote a song he would immediately summon her to play it to the music. ${ }^{41}$ In addition, Shi once wrote in Nanjing a short xiaoling song for a singsong girl named Zhang. ${ }^{42}$ This suggests yet another dimension of his $q u$ writing, namely that it was related to the entertainment quarters, an important aspect of that activity in mid-Ming Nanjing. ${ }^{43}$

For Shi Zhong, who was both an artist and a songwriter, the acts of songwriting and painting sometimes converged in his composition. The following inscription on his painting titled "Winter Landscape" (Dongjing 冬景) provides rare and invaluable evidence on how these two forms of composition were integrated into one common medium:

\footnotetext{
38) JLSS, 3.160a. For a discussion of Wu Wei's paintings, see James Cahill, Parting at the Shore, 98-106.

39) Zhang Huijian 張慧劍, ed., Ming Qing Jiangsu wenren nianbiao 明清江蘇文人年表 (Shanghai: Shanghai guji chubanshe, 1986), 139.

40) Shi Zhong's songs also include a rather bland and conventional piece written in the tradition of boudoir laments. See QMSQ, 413-14.

41) JLSS, 3.159b. See also Shi Zhong's poem titled "Dingsi zhengyue pipa Zhang jiaoshi lai Jiangdong Baiyun geng yu zheng zhi” 丁巳正月琵琶張教師來江東白雲更與證之, in Qian Qianyi 錢謙益 comp., Liechao shiji 列朝詩集, 1652 edition (rpt. Shanghai: Sanlian shudian, 1989), 380, lower column.

42) QMSQ, 414.

43) This aspect of $q u$ writing is well illustrated in the songs of Chen Duo discussed in detail in the next section.
} 
[To the tunes of Duiyuhuan and Qingjiangyin in binary form 對玉環帶清江引]:

Snow piles on the empty mountains,

The world has come to the end of the year.

Ice freezes over the cold river,

A man holds out his fishing line.

There may be fresh wine and a familiar neighbor [as a drinking companion],

But I have no money to drink up those vessels and cups.

Plum blossoms open in the southern village,

Pure fragrance fills the twigs.

Walking in the snow, one ought to pluck [the flowers], ${ }^{44}$

Meng Jiao writes his poem while riding a donkey. ${ }^{45}$

Seeking plum blossoms, Meng Jiao writes his poem while riding a donkey,

Uncertain whether to use the word "shove" or "knock." 46

In the golden embroidered curtain, drinking Yanggao wine, ${ }^{47}$

Whose work can be popular throughout all the streets and markets?

Fit for ridicule is this white-haired old fool!

Bangshen from my clan ${ }^{48}$ is an eminent scholar and a friend of mine. He is interested in various things and has wide-ranging capabilities, and profoundly loves the cultivated arts. My friends Langxian and Xichang are also close friends with Bangsheng. ${ }^{49}$ Bangsheng asked me to draw a small landscape painting for his

44) This refers to an anecdote about Meng Haoran 孟浩然 (689-740) braving the snow to look for the first plum blossoms in winter, popularized first in a play titled Dongyinshi taxue xunmei 凍吟詩踏雪尋梅 (alternatively titled Fengxue qilü Meng Haoran 風雪騎驢 孟浩然) by the Yuan playwright Ma Zhiyuan 馬致遠 (ca. 1250-before 1324), now lost, and later in another play written in 1432 by the princely playwright Zhu Youdun and titled Meng Haoran taxue xunmei 孟浩然踏雪尋梅. See Wilt L. Idema, Dramatic Oeuvre of Chu Yu-tun, 103. This anecdote on Meng Haoran is also popular in Yuan sanqu songs. But here Meng Haoran has become the poet Meng Jiao (751-814) who lived half a century after him.

45) Here Shi Zhong may possibly be alluding to a Yuan sanqu by Chen Dehe 陳德和 (fl.1331): one of Chen's set of ten songs on winter is entitled "[Meng] Haoran riding a donkey" (Haoran qilï 浩然騎驢), but the song is actually about Meng Jiao. See Sui Shusen 隋樹森, ed., Quan Yuan sanqu 全元散曲 (Beijing: Zhonghua shuju, 1964), 1312. The next line (at the beginning of the next stanza) also follows a similar pattern. Shi Zhong appears to have been somewhat free in his use of anecdotes about Tang poets composing poems while riding donkeys.

46) This is yet another famous anecdote about a Tang poet riding a donkey, viz. Jia Dao 賈島. Jia was so absorbed in his choice over the two verbs that he failed to get out of the way of the palanquin of Han Yu 韩愈, who was then a high official.

47) These are common expressions in Yuan dynasty songs.

48) The word jia 家 before Bangsheng's name suggests either that the latter belonged to Shi Zhong's clan or family, or that they simply shared the same surname. Note that in the inscription Shi Zhong wrote the name "Bangsheng" starting a new line, which suggests that Bangsheng might be a more senior figure.

49) I have not been able to determine the identities of these friends of Shi Zhong. 
pleasure in travelling. I really am not capable of doing it, but yet I could not turn him down. Hence, I painted the views of the four seasons, and also composed four short song ${ }^{50}$ titled "[to the tunes of] Duiyuhuan and Qingjiangyin in Binary Form." In shame I hereby present [the paintings and songs] together to those of our times who are skilful in these arts, so as to fulfill my duty as a friend.

On the third day of the second winter month in the first year of the Zhengde reign of the great Ming (17 November 1506), the seventy-year old Shi "the Fool" from east of the river writes this at the Tower of the Reclining Fool.

\author{
雪積空山, \\ 乾坤歲暮時。 \\ 冰凍寒江, \\ 有人垂釣絲。 \\ 新酒熟鄰, \\ 無錢空卢巵。 \\ 梅放南村, \\ 清香滿樹枝。 \\ 踏雪須攀, \\ 孟郊驢背詩。 \\ 探梅華孟郊驢背詩, \\ 不穩推敲字。 \\ 金帳飲羊羔, \\ 那個通街市, \\ 堪笑皓然痴老子。 \\ 家 \\ 邦盛俊彥, 與痴為游。而邦盛好事博能, 重愛斯文。吾友浪仙、希昌與邦 \\ 盛更交莫逆。邦盛欲痴作小景山水, 為行寓清賞。痴本不能, 又不可卻。 \\ 乃寫四時風景, 更作小詞四閶, 曰對玉環帶清江引。並醜於時工者也, 則 \\ 可以盡友道。大明正德改元仲冬三日七十公江東史痴書於臥痴樓。51
}

What is most intriguing about this inscription is that its first half actually preserves the full text of the song accompanying the "Winter Landscape" painting! ${ }^{152}$ This opens the possibility of a new area of

\footnotetext{
50) The term $c i$ 詞 (lyrics) is commonly used to refer to sanqu songs.

51) For the painting and the inscription, see Osvald Sirén, A History of Later Chinese Painting (New York: Hacker Art Books, 1978), vol. 1, pl. 63. My translation of the inscription differs from the earlier one by Stephen Lee Little in two respects. First, Little seems unaware that the first half is a song text and therefore treats it as prose. Second, he translates the tune title of the song and two subsequent lines toward the end of the inscription as part of a poem, but I believe these are prose lines. Cf. Little, "Du Jin, Tao Cheng, and Shi Zhong," 215.

52) Shi Zhong's song and the rest of the inscription are recorded in $Q M S Q$, 414-15, based on a "hand-copied edition" (chaoben 鈔本), but no further details on the source are given.
} 
research devoted to the various media in which sanqu songs were preserved and through which they were transmitted.

The second half of the inscription informs us of the context wherein Shi Zhong created the painting and the song. It records the completion of what appears to have been a set of four landscape paintings representing the four seasons, and of four songs to accompany the respective paintings, in response to a friend's request. Out of this, however, only the painting and song on "Winter Landscape" appear to have survived. This is another confirmation that Shi Zhong's corpus of sanqu songs vastly exceeded his extant ones.

The context in which Shi composed his songs deserves our attention as it suggests a world of $q u$ writing that was clearly outside the milieu of court entertainment in early Ming Nanjing. In place of professional performers writing songs for the court, we now have writers who compose songs in leisure and for their own interest and amusement.

Writing $q u$ indeed became part of their cultural and social life, as can be seen in the exchange of songs among literati. For example, one obscure writer by the name of Wang Chunquan 王春泉, about whom we know almost nothing, ${ }^{53}$ once wrote a song suite dedicated to Shi Zhong in which he eulogized Shi's superior and incorrupt character as well as his skills in singing, painting, and calligraphy. As an occasional song it is filled with general praise and clichés, but it also shows an effort at personalizing the song with more specific references to Shi's residence and to his concubine in the following lines:

Flower vases and wine goblets,

These are readily prepared at the Tower of the

Reclining Fool throughout the four seasons.

[As for someone] to accompany you in appreciating songs and assist you in grading them,

Even if "Dawn Clouds" and "Colorful Clouds" were available,

You wouldn't exchange "White Clouds" for them!
花尊、酒尊，

臥痴樓四季長安頓。

陪賞鑑、助評論,

縱有朝雲共彩雲,

不換白雲。54

This $Q M S Q$ version features some variants with the original inscription on the painting, meaning that the "hand-copied edition" must have come from a secondary source.

53) Wang Chunquan has only two extant xiaoling and one song suite. See QMSQ, 417-19.

54) $Q M S Q, 418$. 
To a reader unfamiliar with Shi Zhong the last lines may present some difficulty: one may know that "Dawn Clouds" was the name of Su Shi's 蘇軾 (1037-1101) concubine- and Wang Chunquan, in an earlier line of the song, actually compared Shi Zhong's calligraphy to that of Su Shi-and "Colorful Clouds" must refer to another beauty, but the reader needs to be aware that "White Clouds" is Shi Zhong's concubine to be able to make sense of the last two lines.

Apart from Wang's song suite, another sanqu was dedicated to Shi Zhong, the title of which, "Collecting Song Names to Congratulate Shi 'The Fool' on His Birthday” (Ji quming shou Shi Chi 集曲名壽 史癡), suggests that it was meant to celebrate Shi's birthday by wittily pastiching tune titles in the arias. ${ }^{55}$ More significantly, this song suite was written by Chen Duo, a major author among the first generation of Nanjing $q u$ writers, to whom we now turn..$^{56}$

\section{Chen Duo: Military Official and "King of Music"}

Dasheng [Chen Duo], who served as a military official, once went to the [southern] capital on transportation duty. A guest held a banquet for him and summoned performers from the Court Entertainment Bureau to play music and wait on them, but Dasheng kept on criticizing [what they were doing]. The performers rejected his comments, the reason being that at first they did not know how excellent Dasheng was in music. Dasheng thereupon took hold of their pipa, and right from his seat he played it and sang a song in fast tempo. The performers could not help submitting in awe, they fell on their knees, kowtowed and said, "We have never heard or seen anything like this"; and they called Chen "King of Music." 大聲為武弁, 嘗以運事至都門, 客召宴, 命教坊子弟度曲侑之。大聲隨 處雌黃, 其人距不服, 蓋初未知大聲之精於音律也。大聲乃手攬其琵琶, 從座上快彈唱一曲。諸子弟不覺駭服, 趾地吒頭曰：“吾儕未嘗聞且見 也。”稱之爲 “樂王”。57

While Shi Zhong appears to have been totally removed from the court milieu of song-writing, the case of Chen Duo-or the "King of Music,"

\footnotetext{
55) See QMSQ, 646-47.

56) Apart from this congratulatory birthday song suite, Chen Duo also drew a landscape painting with an inscribed poem for Shi Zhong. See Chen Zuolin 陳作霖, Jinling tongzhuan 金陵通傳 (rpt. Taipei: Chengwen chubanshe, 1970), 14.8b.

57) Kezuo zhuiyu, 179-80; cf. Grant Guangren Shen's translation in his Elite Theatre in Ming China, 1368-1644 (New York: Routledge, 2005), 30.
} 
as the court performers dubbed him-is more complex. On the one hand, as a military official Chen was associated with the capital in Nanjing and knew its court entertainers, as this anecdote indicates, and he was therefore familiar with the theatrical practices and songwriting activities in the court. On the other hand he cannot be regarded as a court professional writer and appears to have composed $q u$ outside the court and in relative independence: at least there is no evidence that he wrote songs or drama to meet the specific demands of court entertainment.

Often referred to by his courtesy name Dasheng 大聲 or his sobriquet Qiubi 秋碧, Chen Duo is probably the most important qu writer in the second half of the fifteenth century and should be considered a key figure in the first generation of $q u$ writers in Nanjing. His extant sanqu corpus includes a total of 471 xiaoling and 99 song suites, ${ }^{58}$ or more than the total of all the other Nanjing writers combined. Moreover, his songs were frequently cited and selected for inclusion in $q u$ anthologies, which is a sign of their popularity and reputation. ${ }^{59}$ Three plays (of which two are extant) are also attributed to Chen, ${ }^{60}$ but it is a fact that his reputation rested almost entirely on his sanqu songs, his dramatic works being in fact little known and rarely mentioned. ${ }^{61}$

58) This is based on Xie Boyang's calculation. See QMSQ, “Mulu” 目錄, 34. This number includes four xiaoling and eight song suites attributed to different writers by other sources. Issues of authorship and textual problems in Chen's $q u$ writings will be discussed later. 59) On Chen Duo's songs included in the major $q u$ anthologies of the Ming, see Zhao Jingshen 趙景深, “Mingren sanqu de jiyi” 明人散曲的輯逸, in his Ming Qing qutan 明清曲談 (Shanghai: Gudian wenxue chubanshe, 1957), esp. 134-39; and Zheng Qian 鄭騫, “Chen Duo (Dasheng) ji qi ciqu” 陳鐸（大聲）及其詞曲, in his Jingwu congbian 景午叢編 (Taipei: Zhonghua shuju, 1972), esp. 259-67. A few Ming critics held a less favorable opinion of Chen Duo's songs. For example, Wang Shizhen 王世貞 (1526-90) once commented that Chen's songs copied heavily from others, and that he was "shallow in his talent.” See Wang Shizhen, Quzao 曲藻, in Zhongguo gudian xiqu lunzhu jicheng, vol. 4, 36. It is noteworthy that Wang insisted on Chen's military background, which may have been a cause for bias on his part. Gu Qiyuan appears to have shared this condescending view and once referred to Chen derogatorily as a wufu 武夫 (military man); see Kezuo zhuiyu, 180.

60) See Fu Xihua 傅惜華, Mingdai zaju quanmu 明代雜劇全目 (Beijing: Zuojia chubanshe, 1958), 109; Zhuang Yifu, Gudianxiqu cunmu huikao 古典戲曲存目彙考 (Shanghai: Shanghai guji chubanshe, 1982), 417-18. For the story plots of his two extant plays, see Li Xiusheng 李修生 et al., eds., Guben xiqu jumu tiyao 古本戲曲劇目提要 (Beijing: Wenhua yishu chubanshe, 1997), 180-81.

61) This is why I focus on Chen's sanqu songs in this study. For a study of his dramatic works, see Wilt L. Idema, "Yüan-pen as a Minor Form of Dramatic Literature in the 
Although one of the most important $q u$ writers of the mid-Ming, Chen Duo remains an enigmatic figure. As with most $q u$ writers from this relatively early period, sources about his life and writings are scarce. ${ }^{62}$ To begin with, his dates are conjectural: while most accounts of his life are taken from two works-JLSS and Gu Qiyuan's 顧起元 (15651628) Kezuo zhuiyu 客座贅語 (Superfluous talk from the guests' seat, 1618) — neither provides his exact dates of birth and/or death. Modern scholars do not agree either, and various dates have been suggested, such as "ca. 1454-1507" or "ca. 1460-ca. 1521." ${ }^{63}$ The main question is the year of Chen's death-1507 or about 1521? Since Li Kaixian, our earliest source, gives $1507,{ }^{64}$ and that the late-Ming critic Shen Defu 沈德符 (1578-1642) states that Chen lived during the Chenghua (1465-1487) and Hongzhi (1488-1505) periods, ${ }^{65} \mathrm{I}$ am inclined to take the earlier date (1507) as the actual year of Chen's demise.

Chen's social status is ambiguous, too. He was born to a military family, and as a descendent of Chen Wen 陳文 (1325-1384) he held a hereditary post of Guard Commander. We can assume that he led a rather affluent life, judging at least from the fact that he is said to have built numerous halls and pavilions in his residence. ${ }^{66}$ Bearing in mind that Chen held a military office, it is also interesting to consider how

Fifteenth and Sixteenth Centuries," Chinese Literature: Essays, Articles, Reviews 6 (1984): 66-68, which gives a detailed introduction to one of Chen's plays, Taiping leshi 太平樂事 (Great Peace Entertainment). This is, to my knowledge, the only Western-language study discussing Chen's dramatic work. I would also like to thank Professor Idema for sharing with me his photocopy of this play. The original versions of Chen Duo's two extant plays are kept in the National Library of China in Beijing.

62) For biographical information on Chen Duo, see Zheng Qian, "Chen Duo (Dasheng) ji qi ciqu," esp. 249-52. For brief introductions in English, see the relevant entries in William H. Nienhauser et al., eds., The Indiana Companion to Traditional Chinese Literature (Bloomington: Indiana Univ. Press, 1986), 235-36, and L. Carrington Goodrich and Chaoying Fang, eds., Dictionary of Ming Biography (hereafter DMB) (New York: Columbia Univ. Press, 1976), 184-85.

63) See respectively QMSQ, 446, and Li Changji 李昌集, Zhongguo gudai sanqu shi 中國 古代散曲史 (Shanghai: Huadong shifan daxue chubanshe, 1991), 651. Zheng Qian also believes that Chen might have died in the early years of the Jiajing period, i.e., sometime in the 1520s; see his "Chen Duo (Dasheng) ji qi ciqu," 251.

64) Li Kaixian, “Xiye Chunyouci xu” 西野《春遊詞》序, in Li Kaixian quanji 李開先 全集, ed. Bu Jian 卜鍵 (Beijing: Wenhua yishu chubanshe, 2004), 494.

65) Shen Defu, Guqu zayan 顧曲雜言, in Zhongguo gudian xiqu lunzhu jicheng, vol. 4, 202.

66) See Chen Yifu 陳詒袚, Jinling yuanshu zhi 金陵園墅志, cited in QMSQ, 696. 
his involvement in $q u$ writing was perceived by his contemporaries. The following anecdote may give us a clue:

Guard Commander Chen Duo was famous for his lyrics and songs. On one occasion, he paid a call on the Duke of $\mathrm{Wei}^{67}$ in the latter's residence [to discuss] garrison affairs. Master Xu [the Duke of Wei] asked: "Are you the Chen Duo who is adept at composing lyrics and songs?" Chen replied, "Yes, I am." Xu then asked, "Can you sing as well?" Chen thereupon pulled an ivory clapper from his sleeve and sang a song. Master Xu waved him away, and said, "Chen Duo is a Guard Commander with a golden belt, he does not work for the court, he carries an ivory clapper along—how lowly!"

指揮陳鐸以詞曲馳名。偶因衛事謁魏國公於本府。徐公問：“可是能詞曲之 陳鐸乎?”鐸應之曰：“是。” 又問：“能唱乎?”鐸遂袖中取出牙板, 高歌一 曲。徐公揮之去, 乃曰：“陳鐸是金帶指揮, 不與朝廷做事, 牙板隨身, 何 其卑也。”68

This anecdote portrays Chen as an unconventional official who was so preoccupied with his songs that he carried an ivory clapper on him wherever he went. The text suggests that the Duke of Wei disapproved of Chen's infatuation with songs and music, but we need to be careful in drawing any conclusions because such anecdotes stating the adverse effects of song-writing on one's official career are rather common. ${ }^{69}$ Furthermore, we also know that on at least one occasion Chen did in fact write a birthday congratulatory song for the Duke of Wei. ${ }^{70}$ In other words, the Duke may have enjoyed $q u$ as well, and his relations with Chen may not have been as unfavorable to the latter as is described here. What the present anecdote possibly suggests is that Chen Duo had crossed the line of propriety: it might be acceptable to enjoy wine and music in the company of courtesans, or even write songs occasionally, but to be personally involved in actual performance and carry a musical instrument in one's sleeve was a step too far.

67) That is to say, $\mathrm{Xu} \mathrm{Fu}$ 徐俌 (1450-1517), who inherited the position first held by Xu $\mathrm{Da}$ 徐達, the general who helped the Hongwu emperor capture Beijing.

68) JLSS, 3.164b.

69) This account of Chen Duo is reminiscent of the famous anecdote on Liu Yong 柳永 (987-1053) being denied official appointments because of his status as a writer of popular songs. See James R. Hightower, “The Songwriter Liu Yong: Part I," Harvard Journal of Asiatic Studies 41 (1981), esp. 325-27.

70) Chen Duo, “Shou Xu Weigong”壽徐魏公, QMSQ, 636. 
Chen Duo, however, appears to have been unaffected by the way others perceived him and to have freely enjoyed his lifestyle. This is clearly expressed in an autobiographical song suite titled "Zishu” 自 述 (A statement about myself):

To the tune of Yizhihua 一枝花 under the Northern Nanlü 南吕 mode:

Doing poetry and prose, I've long had a 事詞章舊有名, reputation for it,

For grabbing the gaiety of romances, I'm brimful 攬風月多才71俊。 of talents.

When it comes to commenting on the rise and fall of dynasties, I always keep my mouth shut;

Longing for wealth and honor, I'm afraid, would weary my mind.

Looking back at my youthful days,

I am now close to thirty years old,

My lofty aspiration to cultural brilliance remains unfulfilled.

Hence, with my brush tip I grade the willows and comment on the blossoms, ${ }^{72}$

In my heart I roll the fragrances round and fondle the powder.

說興亡常閉 $\square$,

期富貴怕勞神。

回首青春,

又早三十近,

虹霓志未伸。

因此上筆尖兒判柳評

花,

心性兒摶香弄粉。

To the tune of Liangzhou diqi 梁州第七:

My ears like to listen to the "The Jacket of Golden Threads" sung softly. ${ }^{73}$

My eyes love to watch the red skirts's marvelous dance.

This is because I was born with this reckless and brusque lot:

\section{耳邊廂喜㯖的是輕歌金 縷, \\ 眼根前愛看的是妙舞紅 裙。 \\ 也是我生平注下疎狂 \\ 分：}

\footnotetext{
71) In the Ming edition of Chen Duo's songs this character is written 婹, whose meaning is unclear. See Zuoyin xiansheng jingding Chen Dasheng yuefu quanji 坐隱先生精訂陳大 聲樂府全集, in Xuxiu Siku quanshu 續修四庫全書, vol. 1738, 330, and also QMSQ, 592. I have followed the variant reading cai 才, found in the qu anthology Yongxi yuefu 雍熙 樂府, j. 10. See Lidai sanqu huizuan 歷代散曲彙纂 (Hangzhou: Zhejiang guji chubanshe, 1998), 284.

72) Willows and blossoms are commonly used to refer to courtesans in pleasure quarters. 73) “Jinlüyi” 金縷衣 (The Jacket of Golden Threads) is the title of a famous Tang quatrain in the voice of a woman who advises her lord not to neglect the time of her blossoming youth.
} 
My hands are skilful, like those of Zhang Chang;

My tongue is sharp, similar to that of Su Qin;

My temperament is romantic, like that of $\mathrm{Du}$ $\mathrm{Mu} ;^{74}$

My belly is wide [i.e., I am generous], similar to that of Tian Wen [Lord Mengchang].

My words are honest and respectful, being a refined scholar;

My bones are unbending, being a young nobleman.

The dew on the lotus flowers dampens my official cap as I return late every night;

The moon over the wutong tree shines into the gauze curtains as I sleep soundly.

The [scent of] cassia flowers in the wind exhilarates this poet's robe as I roam day after day.

I reflect upon myself,

I consider my doings,

Carrying on my father's trade, I just wait for a prosperous fortune [to fall upon me].

I save myself from begging [for jobs] and dismiss all discussions.

Softly echoing the waters of Canglang ${ }^{75}$, I quietly close the gate,

To turn away from the rolling red dust in this world of mortals.

To the tune of Shawei 憊尾:

If one day [His Majesty's] trust flies from mid-air like wind and thunder,

And [His] favor spills on the ground like rain and dew,

Then I will hold my token of authority and grasp my spear to guard the military camp,
手段兒熟猾如張敞， 舌頭兒利便似蘇秦, 性格兒風流如杜牧,

肚皮兒豁達似田文。

語言直敬的是斯文，

骨頭高傲的是王孫。

芙蓉露濕烏紗夜夜歸 遲,

梧桐月照羅幔齁齁睡 穩,

桂花風爽吟祀日日遊 頻。

自思,

自忖。

保箕政且待亨通運,

省干求罷談論,

細和滄浪靜掩門，

且迴避滾滾紅塵。

\section{有一日半空中飛下風雷} 信,

平地裏分來雨露恩。

那其間執節操戈把柳營 鎮,

74) Zhang Chang drew his wife's eyebrows; Su Qin is the famous strategist; as for the Tang poet Du Mu (803-852), Chen Duo mentions him as a model in several of his songs: see e.g., QMSQ, 659.

75) A reference to the famous song sung by the fisherman whom Qu Yuan met as recorded in “Yufu” 漁父 (The Fisherman). See Ma Maoyuan 馬茂元 et al., eds., Chuci zhushi 楚辭註釋 (Wuhan: Hubei renmin chubanshe, 1999), 7.390. For a translation, see David Hawkes, trans. The Songs of the South: An Ancient Chinese Anthology of Poems (Harmondsworth, Middlesex: Penguin, 1985), 207. 
Uphold my loyalty in serving the sovereign,

秉精忠為君，

Preserving my purity in caring for the people;

Having accomplished these few services, I shall 守清白愛民， 酬得那些勳勞 then retire into seclusion.

便歸隱。7 76

One observes an interesting interfusion of two different voices and contrasting ideals in this suite. On the one hand, it starts with Chen's self-portrayal as a romantic songwriter staying away from political affairs and only wishing to spend his time in the pleasure quarters among singsong girls. And on the other hand, we also see that he was under no illusion that he really could free himself from the concerns and worries of officialdom. Having inherited a military post, he was aware of his responsibilities and made constant reference to his "official cap," or even spoke of "carrying on his family's trade." Toward the end of the song Chen Duo addresses his duties as a Guard Commander with such patriotic voice that he is almost unrecognizable as the romantic songwriter of the opening lines.

Though an important and popular $q u$ writer in the Ming, Chen Duo has for the most part received rather low appraisals from critics of the twentieth century. For example, Zheng Qian 鄭騫 (1906-1991) considers his songs second-rate when compared to those of other midMing writers such as Wang Jiusi or Kang Hai. ${ }^{77}$ To understand the grounds for such criticism, however, we need to look at the history of the textual transmission of Chen's songs and wonder whether all of them were indeed available to the earlier generation of scholars.

In 1611, Wang Tingne 汪廷訥 compiled the Zuoyin xiansheng jingding Chen Dasheng yuefu quanji 坐隱先生精訂陳大聲樂府全集 (A complete collection of Chen Duo's $q u$ writings carefully edited by sir Zuoyin, hereafter Complete Collection). ${ }^{78}$ This is the most complete collection of $q u$ writings attributed to Chen Duo, consisting of his five

\footnotetext{
76) QMSQ, 592.

77) Zheng Qian, “Chen Duo (Dasheng) jiqi ciqu," 259. In this case, Zheng's negative comments on Chen's songs appear to be unrelated to Chen's military background as was the case we have seen earlier in some traditional critics, cf. n. 59 above. Zheng Qian not only praised Chen highly for his broad knowledge and talents, but also argued that while some critics regarded Chen as a descendant of a military family, Chen was in fact more like a literatus (wenren Mingshi 文人名士); p. 251.

78) See Xu Shuofang 徐朔方, Wan Ming qujia nianpu 晚明曲家年譜 (Hangzhou: Zhejiang guji chubanshe, 1993), vol. 3, 543. Yuefu in the title is commonly used to refer to sanqu songs and drama.
} 
sanqu collections-namely, Liyun jiao 梨雲寄傲 (two juan), Qiubixuan gao 秋碧軒稿 (one juan), Kexuezhai gao 可雪齊稿 (one juan), Yuexiangting gao 月香亭稿 (one juan), and Huaji yuyun 滑嵇余韻 (one juan)_and two plays, Najinlang chuanqi 納錦郎傳奇 and Taiping leshi 太平樂事. Complete Collection is now held at the National Library in Beijing, except for Huaji yuyun, which is in the collection of the Theater Research Institute of the Chinese Academy of Arts (Zhongguo yishu yanjiuyuan xiqu yanjiusuo 中國藝術研究院戲曲研究所). All five sanqu collections have been reproduced in the Xuxiu Siku quanshu 續修四庫全書 series. ${ }^{79}$ Chen's songs are also included in the QMSQ collection in a modern typeset edition. ${ }^{80}$

Yet for a very long period of time much of this material was unavailable to scholars working on sanqu. In the absence of Complete Collection, early scholars could only rely on two juan of Chen's songs in manuscript editions, namely, (1) Qiubi yuefu 秋碧樂府 and, (2) Liyun jiao 梨雲寄傲, hereafter referred to as QBYF (MS) and LYJA (MS) to differentiate them from the printed versions in Chen's Complete Collection, which have very similar titles. ${ }^{81}$ These two collections, also held at the National Library of China, were made available as early as the 1930s when they were included by Lu Qian 盧前 (1904-1950) in his series of reprints of Yuan and Ming sanqu, the Yinhongyi suoke qu 飲虹簃所刻曲. ${ }^{82}$ Until recently they have been the main source for researchers. Without access to Complete Collection, scholars such as Zhao Jingshen 趙景深 (1902-1984) and Zheng Qian were still trying

79) Xuxiu siku quanshu (Shanghai: Shanghai guji chubanshe, 2002), vol. 1738, 307-421. 80) QMSQ, 446-719. Note that Wayne Schlepp's entry on Chen Duo in the Indiana Companion to Traditional Chinese Literature lists Complete Collection as one of the editions of his works (p. 235); however, its description of Chen's sanqu corpus states that he only left behind three sanqu collections, which does not match the actual contents of Complete Collection.

81) The most confusing case is Liyun ji'ao, because the manuscript and printed editions share the same title, when the latter (in Complete Collection and its reprints) contain many more songs than the former. It is unclear whether the manuscript editions predate or postdate Complete Collection. The editor of QMSQ believes that both one-juan manuscript editions were selected from the eight-juan Complete Collection edition, implying that they are posterior to it, but he does not explain his reasons for saying so. See QSMQ, 707, n. 178. It seems to me equally possible that the manuscripts were already in circulation when the Complete Collection was printed, since their titles are among those mentioned by Zhou Hui in his JLSS, whose preface is dated 1610, while Complete Collection was only printed in 1611 .

82) See Lu Qian, ed., Yinhongyi suoke qu (1936; rpt. Taipei: Shijie shuju, 1985), vol. 1. 
to recover Chen's songs from Ming anthologies, respectively in the 1940 s and in $1970 .{ }^{83}$ As recently as the 1980 s a new edition of Chen Duo's songs was published, based on the same two manuscripts, to which the recently discovered Huaji yuyun was added; the editor actually claimed that the Complete Collection is no longer extant! ${ }^{84}$

The fact that before the 1990s scholars had little or no access to Chen Duo's full corpus of songs has influenced considerably the appraisal of Chen's sanqu compositions. The impression of a reader with access to the two manuscripts only is bound to be very different from that of a reader able to consult the Complete Collection. The two manuscripts contain mostly southern songs and romantic love songs. As Ren Ne 任昞 (1897-1991) remarked, the majority of the songs in QBYF (MS) are about the "boudoir." ${ }^{55}$ This may explain why earlier scholars summarized Chen's style as "gentle and seductive" (roumei 柔媚), since their opinions were only based on QBYF(MS) and LYJA (MS) ${ }^{86}$ In contrast, when one reads through the complete song collection of Chen Duo, one cannot help but be impressed by the variety of styles demonstrated and wide range of topics addressed: he covered almost all the main themes of the sanqu genre. ${ }^{87} \mathrm{He}$ also wrote on all walks of life of the Ming society, especially in his collection of 141 xiaoling in Huaji yuyun. ${ }^{88}$

There is no denying that among Chen Duo's considerable oeuvre are some songs that are rather average and not very interesting. For

83) See Zhao Jingshen, "Mingren sanqu de jiyi," esp. 134-39, and Zheng Qian, "Chen Duo (Dasheng) jiqi ciqu," esp. 259-67.

84) Yang Quanzhang 楊權長, ed.,Chen Duo sanqu 陳鐸散曲, Sanqu juzhen 散曲聚珍 series (Shanghai: Shanghai guji chubanshe, 1989), “Qianyan” 前言, 1, 5. The preface to this edition is dated 1986.

85) Ren Ne, Quxie 曲諧, Sanqu congkan 散曲叢刊 edition (1931; rpt. Taipei: Zhonghua shuju, 1984), 3.52b.

86) See, e.g., Luo Jintang 羅錦堂, Zhongguo sanqu shi 中國散曲史 (Taipei: Zhonghua wenhua chuban shiye weiyuanhui, 1966), 147.

87) This has been well argued by Li Changji in his 1991 Zhongguo gudai sanqu shi; see, esp. 653-56. As a student of Xie Boyang (the editor of QMSQ), Li Changji may have been one of the earliest Chinese scholars with access to the full body of Chen Duo's works, hence his much different appraisal of Chen's songs, compared to that of earlier scholars. Li does refer (see 653) to the vast number of Chen Duo's songs collected by Xie Boyang in $Q M S Q$, which was then only about to be published.

88) See Xia Xianchun 夏咸淳, “Ming zhongye shijing baixiang: lun Chen Dasheng sanqu ji Huaji yuyun” 明中葉市井百像 : 論陳大聲散曲集《滑稽餘韻》, in Xinshiji quxue yanjiu wencun liangzhong 新世紀曲學研究文存兩种, ed. Zhao Yishan (Shanghai: Shanghai guji chubanshe, 2003), 287-97. 
example, his songs on the theme of reclusion and withdrawal are fairly conventional. ${ }^{89}$ Furthermore, some of the boudoir laments or love songs are so generic that when they are mixed with songs on the same theme by other writers one cannot really tell them apart. As a matter of fact, the Complete Collection erroneously contains some songs by other writers, most notably by the early Ming writer Zhu Youdun. ${ }^{90}$ All of this reveals the conventional side of Chen's $q u$ writings, a tendency merely to follow the earlier tradition.

Yet a closer study of his works reveals that he seemed to enjoy taking up a conventional theme and then varying it. This is clearly demonstrated by his songs on entertainment quarters. On one hand we find very cliché works on the pleasure district, such as his two sets of ten xiaoling songs titled "Ten Songs on the Green Tower" (Qinglou shiyong 青樓十詠), in which the ten steps in a romanticized "routine" of pleasure seeking in entertainment quarters are outlined, following the tradition set by the Yuan writer Xu Yan 徐琰, ${ }^{91}$ or another set of ten songs titled “Ten Songs on Beauties” (Meiren shiyong 美人十詠), giving sensual descriptions of the female body. ${ }^{92}$ But on the other hand, we also find Chen telling the other side of the story and revealing the brutal and heartless reality in the entertainment quarters. One example is his set of four songs on "Mocking Those Who Said that Nanjing Courtesans Are Good” (Chao ren yan Nanjing jinü hao 嘲人 言南京妓女好). ${ }^{93}$ The first starts with the following lines:

[Some say the courtesans of] the Northern Capital are devoid of sentiments,

北京的寡情，

89) See, e.g., his set of four songs on reclusion as a fisherman in QMSQ, 457-58.

90) The editor of $Q M S Q$ duly points out this problem. See, e.g., QMSQ, 703-705, nn.125, $127,132,134$, and 138 .

91) See QMSQ, 469-72 and 498-500. For Xu Yan's original set, see Quan Yuan Sanqu, 80-83. The title of Chen Duo's “Ten Songs on the Green Tower" in Complete Collection is followed by a note stating that the set adopts a title once used by one Xu Zunhui. See Xuxiu siku quanshu edition, 336, and QMSQ, 469. This may be why the editor of QMSQ introduces Xu Zunhui as a "friend" of Chen's. Only three songs of Xu's original set are preserved. See QMSQ, 794-95. However, I have found that two of his songs are identical to songs by Xu Yan of the Yuan. Cf. Quan Yuan Sanqu, 82-83. This raises questions about their authorship.

92) QMSQ, 514-17.

93) QMSQ, 487-88. 
While those of the Southern Capital are more sentimental.

North or South, they share the same character -

All are pits to entrap people!
南京的有情。

南與北同心

性,

一般都是陷人 坑。94

The simple message that Chen wishes to convey is that the courtesans, whether from Beijing or Nanjing, are just equally heartless. His other works in the same vein include a set of six songs mocking those who indulge in frequenting the entertainment quarters too much, and a song suite advising such patrons to restrain themselves. ${ }^{95}$

Chen Duo's songs devoted to the city of Nanjing in general offer the same kind of contrasts. He praises its glamour and splendor in his many song suites devoted to the celebration of the Lantern Festival there, ${ }^{96}$ and likewise in another song recounting the illustrious history and legacy of the city, which closely follows the yongsh $i$ 詠史 (contemplation of the past) tradition often encountered in shi poems and ci lyrics on Nanjing. ${ }^{97}$ But Chen also reveals the "darker" side of the city, with a profusion of immoral professions and trades based on cheating lurking behind the veil of glamour. ${ }^{98} \mathrm{He}$ is especially critical of people exploiting popular religious beliefs, such as the priests, nuns, fortune tellers, temple attendants, and other sacrificial officers. The following song, which mocks a geomancer, is an example:

To the tune of Shuixianzi 水仙子:

Seeking out the "dragon den,"”9 inverting the water flow—-this is all wasted attention;

尋龍倒水費殷

勤,

\footnotetext{
94) QMSQ, 487.

95) See respectively “Chao ren lan yu huajiu” 嘲人濫於花酒, $Q M S Q, 494$, and “Quan zidi shouxin” 勸子弟收心, 602-3.

96) See QMSQ, 571-72, 633-36, 657-59, 672-73, and 673-74.

97) $Q M S Q, 645-46$. For a comprehensive study of this tradition, see Owen, "Place: Meditation on the Past at Chin-ling," esp. 441-42 for a partial translation of a Yuandynasty song suite on the topic.

98) See Yao Yuguang 姚玉光, “Huaji yuyun: zhiye bing renxing chou de yishu bawo” 《滑 稽餘韻》：職業病人性丑的藝術把握, Yanbei shifan xueyuan xuebao 17.5 (2001): 44-47. 99) The “dragon den" (longxue 龍穴) is a term in geomancy referring to the location on a hill where the geomantic influences are assembled, thereby making it an ideal spot for a burial ground.
} 
Taking a bearing and deciding where a grave should be-there is no universal standard;

[Your theories about] storing the wind and gathering the $q i$ are pure nonsense!

Let me tell you, Mr. Geomancer, you ought to consider this yourself:

Why don't you select one [good spot in the] mountains to bury your ancestors,

Then you'll live in longevity and you'll be blessed; You will be promoted to a high official position, and your fortune will be secure,

Isn't that better than going around begging at the doors of the nobles?

取向薟穴無定準。

藏風聚氣胡談論,

告山人須自忖 :

揀一山葬你先人,

壽又長身又旺, 官又高財又穩，

不強如干謁侯門。100

Such songs introduce us to a dimension of Chen's sanqu that we do not find in the two manuscript editions, and which earlier scholars did not have access to. This sort of mocking and jocular style, with the occasional touch of cynicism, stands out most clearly in the majority of his songs. In some ways Chen Duo was not unlike a caricaturist in writing.

His taste for writing songs like this may have been be related to his personality. It is said that he was fond of mocking others. ${ }^{101}$ Besides, songs of this type are representative of an important stylistic trend during Chen's times. Some of his contemporaries, such as Wang Pan 王磐 (ca. 1455-1524) and Jin Luan, are known to have excelled in the same style. As mentioned earlier, Chen Quan, yet another Nanjing qu writer, was also famous for such playfulness. This tradition of "ridiculing and jesting” (chaoxi 嘲戲) in $q u$ compositions is well represented in the anthology Beigong ciji 北宮詞紀 (A compilation of songs in the northern style), which has an entire section of such songs by Yuan and Ming $q u$ writers. ${ }^{102}$ Significantly, Chen's own Complete Collection contains a volume of sanqu titled Qiubixuan gao 秋碧軒稿 (Manuscripts from the studio of Qiubi [Chen Duo]), which is composed almost

\footnotetext{
100) Chen Duo, “Zangshi” 葬士, QMSQ, 530.

101) Kezuo zhuiyu, 97.

102) See Beigong ciji waiji 北宮詞紀外集, collated and supplemented by Wu Xiaoling 吳曉鈴 (Beijing: Zhonghua shuju, 1961; Taipei: Xuehai chubanshe, 1971 reprint), 2.19-60.
} 
entirely of satires mocking others. It was in such satirical and jocular songs that Chen Duo found his best literary tone.

\section{Xu Lin: Painter, Calligrapher and Court Writer}

Whether Xu Lin should be considered a Nanjing writer perhaps requires a word of explanation, since some scholars, such as Xu Shuofang 徐 朔方 (1923-2007), have discussed him as a Suzhou writer. It is a fact that Xu's family originated from Suzhou and that, as Xu Shuofang has pointed out, in all his inscriptions on calligraphy and paintings he introduced himself as "Xu Lin from Suzhou." 103 Yet, considering that he was born and spent almost his entire life in Nanjing, I believe it more appropriate to see him as belonging to the first generation of Nanjing writers in the mid-Ming. It is significant that the Jinling suoshi also regards him as a Nanjing writer.

Unlike the previous two men, about whom biographical information is scarce, Xu Lin's life is comparatively well documented. A tomb inscription was written for him by Gu Lin 顧璘 (1476-1545), a major literary figure and cultural leader in Nanjing, ${ }^{104}$ and both a biography and a nianpu 年譜 have been compiled by modern scholars. ${ }^{105}$

$\mathrm{Xu}$ Lin was recognized early as a child prodigy, but he later failed to become an official and is said to have proclaimed that a true scholar needs no official position. ${ }^{106}$ Instead, he made his name in cultural circles with his skills in calligraphy and painting. ${ }^{107}$ Through his artwork he also accumulated sufficient wealth to build in 1500 an estate of several acres named “Satisfaction Garden” (Kuaiyuan 快園), where he regularly hosted literati gatherings. ${ }^{108} \mathrm{Xu}$ Lin enjoyed a wide literati network. He was probably one of the artists in the circle of the Nanjing

103) Xu Shuofang, Wan Ming qujia nianpu, vol. 1, 1.

104) Gu Lin, “Yinjun Xu Ziren Lin muzhiming”隱君徐子仁霖墓誌銘, in Guochao xianzheng lu 國朝獻徵錄, ed. Jiao Hong 焦㓍, Mingdai zhuanji congkan 明代傳記叢刊 edition (Taipei: Mingwen shuju, 1991), 115.35a-37a.

105) Hu Shihou 胡世厚 and Deng Shaoji 鄧紹基, eds., Zhongguo gudai xiqujia pingzhuan 中國古代戲曲家評傳 (Zhengzhou: Zhongzhou guji chubanshe, 1992), 250-57, and Xu Shuofang, Wan Ming qujia nianpu, vol. 1, 1-31. See also DMB, 591-93.

106) Gu Lin, "Yinjun Xu Ziren Lin muzhiming," 115.36a.

107) For a list of Xu's extant paintings, see Little, "Du Jin, Tao Cheng, and Shi Zhong," 243 , n. 44.

108) Xu Shuofang, Wan Ming qujia nianpu, vol.1, 10-11, and DMB, 592. 
painter Du Jin 杜堇 (active 1465-1509) during the Hongzhi period. ${ }^{109}$ He was also well acquainted with artists from the Wu region, in particular Wen Zhengming, whose praise of the popularity of Xu's songs is recorded in JLSS, as mentioned earlier. ${ }^{110}$

$\mathrm{Xu}$ Lin is known to have produced an annotated edition of the Zhongyuan yinyun 中原音韻, a rhyming dictionary for northern $q u .^{111}$ This edition is unfortunately lost, but its very mention informs us that $\mathrm{Xu}$ showed special interest in the $q u$ genre. It also shows that writing northern $q u$ perhaps presented certain challenges for him and for his fellow southern writers, which might have prompted the need for such a publication.

$\mathrm{Xu}$ had the financial resources allowing him to produce and orchestrate $q u$ performances. It was said that he loved music and performances by singsong girls and could compose new tunes for entertainment. Whenever he finished writing a song, he would order his boy actors and female servants to perform it. ${ }^{112}$ In contrast with Shi Zhong, who appears to have only had his concubine as his musician, in the case of $\mathrm{Xu}$ Lin we may see an early example of a private drama troupe in Nanjing.

Even though Xu was one of the better-known $q u$ writers in the midMing, the works by him extant today are extremely few. QMSQ collects merely three xiaoling of his and a song suite that he co-wrote with Chen Duo, alongside three songs of questionable authorship that are attributed to other writers elsewhere. ${ }^{113}$ In addition, Xu may also have collaborated with Chen Duo on another set of four xiaoling songs. ${ }^{114}$ As for his dramatic writing, we have seen earlier that according to the

\footnotetext{
109) Little, "Du Jin, Tao Cheng, and Shi Zhong," 24.

110) $\mathrm{Hu}$ Shihou and Deng Shaoji, Zhongguo gudai xiqujia pingzhuan, 252.

111) Huang Yuji 黄虞稷, Qianqintang shumu 千頃堂書目, ed. Qu Fengqi 睢鳳起 and Pan Jingzheng 潘景鄭 (Shanghai: Shanghai guji chubanshe, 1990), 3.96.

112) Gu Lin, "Yinjun Xu Ziren Lin muzhiming," 36a.

113) QMSQ, 799-803.

114) Kezuo zhuiyu, 180-8, where the set is titled “Yong sijing lianju” 咏四景聯句. However, this set of songs appears as the sole composition of Chen Duo, with no mention of $\mathrm{Xu}$ Lin as the co-writer, in Chen's Kexuezhai gao (in the Complete Collection), with the different title “Sishi guiyuan” 四時閨怨. See Zuoyin xiansheng jingding Chen Dasheng yuefu quanji (Xuxiu Siku quanshu, vol. 1738), 384-85, and QMSQ, 506-7. The authorship of the set is further problematized by the fact that it has been attributed to at least five other writers in various anthologies. See QMSQ, 703-4, n. 126.
} 
author of JLSS at least seven plays by Xu were still available by the early seventeenth century. There were also remnant arias from another play of his, preserved in an anthology. ${ }^{115}$ The significant feature regarding Xu Lin as a playwright is that he represented a new trend working with the southern chuanqi 傳奇 genre, which was starting to gain popularity at the time. But attempts to discuss Xu Lin as a dramatist can only be extremely restricted because of a lack of sources. Among his plays, only Xiuruji 綉襦記 (The story of the embroidered jacket), an adaptation of the famous story of Li Wa, has survived. Furthermore, even though $\mathrm{Xu}$ Lin may now be best known as the author of Xiuruji, we should remember that the authorship of the play is not without dispute and that it has been attributed to at least two other playwrights. ${ }^{116}$ More importantly, just as in the case of Chen Duo, Xu's reputation as a $q u$ writer in his time rested almost entirely on his sanqu songs, ${ }^{117}$ none of his plays being recorded in Ming and Qing drama catalogues. ${ }^{118}$

The scarcity of extant sources, however, has not denied Xu Lin his reputation in the history of $q u$ writing. He appears to have made a name for himself not only because of the quality of his songs, but also, and perhaps more, because of the special circumstances in which he wrote them and the people he associated with in the process. The following is one account in this sense:

Huang Lin, zi Meizhi, hosted a banquet in his "Hall of Literary Abundance" [Fuwentang] on the fifteenth day of the first month of the New Year. He summoned many actors and singsong girls and gathered musicians so that [his guests

115) See Huang Shizhong 黃仕忠, “Ming Xu Lin Liuxianji yiqu jikao” 明徐霖《柳仙 記》佚曲輯考, in Mingdai wenxue lunji 2006 明代文學論集 2006, ed. Liao Kebin 廖可斌 (Hangzhou: Zhejiang daxue chubanshe, 2007), 628-37.

116) On the sources, editions, authorship, and collected criticism of Xiuruji, see the appended materials in Wang Fucai 王福才 and Wang Xingrong 王星榮, eds., Xiuruji ping$z h u$ 綉襦記評註, in the Liushizhong qu pingzhu 六十种曲評註 series (Changchun: Jilin renmin chubanshe, 2001), vol. 14, 283-325. For a study of the dramatic adaptations of the story of Li Wa, see Wilt L. Idema, "Shih Chün-pao's and Chu Yu-tun's Ch'ü-chiangch'ih: The Variety of Mode within Form," T'oung Pao 66 (1980): 217-65; Kim Mun-kyung (Kin Bunkyō) 金文京, “Shōsetsu Ri Ai den no gekika-Kyokukōchi to Shüjuki” 小説李娃 傳の劇化一一曲江池と繡襦記, Chügoku bungakuhō 32 (1980): 74-115; Glen Dudbridge, The Tale of Li Wa: Study and Critical Edition of a Chinese Story from the Ninth Century (London: Ithaca Press, 1983), 82-92, 94-99.

117) This is also pointed out by Xu Shuofang in his Wan Ming qujia nianpu, vol. 1, 14. 118) See Fu Xihua, Mingdai chuanqi quanmu 明代傳奇全目 (Beijing: Renmin wenxue chubanshe, 1959), 23-26. 
could] enjoy their performance. Xu Lin and Chen Duo were invited as honored guests. Huang Lin said, "For today's fine occasion, there is no place for old lyrics. May I ask you two masters to co-write a song suite? I will then immediately summon the musicians to play the songs. How would that be?” Thereupon Xu Lin and Chen Dasheng brandished their brushes and worked together in writing a song suite; as soon as they had completed one song Huang ordered his musicians to learn it; and in the end they combined them and played [the entire suite]. Until today it is remembered as a memorable event.

黃琳美之元宵宴集富文堂, 大呼角伎, 集樂人賞之。徐子仁、陳大聲二公 稱上客。美之曰：“今日佳會, 舊詞非所用也, 請二公聯句, 即命工度諸絃 索, 何如? ”於是子仁與大聲揮翰聯句, 甫畢一調, 即令工肆習, 既成合而 奏之, 至今傳為勝事。119

There is one song suite attributed jointly to Chen and Xu that appears to have been composed in a similar context. It is titled "Linked verse by Chen Duo and Xu Lin at Fuwentang" (Fuwentang Chen Dasheng Xu Ziren lian 富文堂陳大聲徐子仁聯) in one anthology, and “Linked verse with $\mathrm{Xu}$ Lin at an early summer gathering at Fuwentang” (Fuwentang chuxia yanji tong Xu Ziren lianju 富文堂初夏讌集同徐子仁 聯句) in Chen Duo's collection. ${ }^{120}$ This suite may not be the one referred to in the anecdote above, since its title in Chen's collection suggests that it was written in early summer and its opening lines describe a late-spring scene, none of which fits the period of the yearfirst lunar month-indicated in the anecdote. If so, it must record yet another collaboration between $\mathrm{Xu}$ Lin and Chen Duo, suggesting that such occasions were not uncommon.

We cannot know how the collaboration worked between $\mathrm{Xu}$ and Chen. It is not said who wrote which part of the arias, but since the suite in question is composed of twelve alternating northern and southern tunes, one wonders whether the two authors might not have been each in charge of one of the two types of aria. The eighth and ninth songs read as follows:

To the tune of Naofanlou 閙柇樓 (Southern):

The deafening playing and singing makes a real

聒耳笙歌正喧炒， racket.

The more we linger around, the higher our spirits. 越盤桓情越好。

120) See QMSQ, 641-43 (Chen Duo's section) and 800-802 (Xu Lin's section). 
When playing games ${ }^{121}$ we yell and scream freely.

Who cares how late it has gone into the night,

[We just stay up] from dusk to dawn.

To the tune of Simenzi 四門子 (Northern):

After I compose this new verse, I ask my host to examine it,

For I'm afraid my haste resulted in musical errors.

The common words, he changes them,

The unfamiliar characters, he weighs them.

He summons female performers and the piece is performed right away.

When tunes and rhymes are harmonious,

When beats and rhythm are regulated,

Then the score is added to the old Yangchun [baixue]. ${ }^{123}$
射覆藏鬪任呼號, 不管人間夜迢迢, 自黃昏直到卯。

賦新詩更請東君校，

怕倉皇音律錯。

將熟字兒更,

生字兒敲。

喚青衣一時敷演着，

腔韻諧,

板拍調,

旋譜入陽春舊稿。122

These arias capture not only the pleasure of the gathering, but also the spontaneous act of composition and immediate performance of the songs, just as in the anecdote mentioned earlier. Moreover, both the suite itself and the anecdote point to a specific locale, the Fuwentang (Hall of Literary Abundance), where Xu Lin's qu activities took place.

The Fuwentang was owned by the rich and powerful Huang Lin 黄 琳, well known for his collections of books, drawings, and antiques. ${ }^{124}$ It appears to have been a meeting place where songs were composed and performed, not only for Xu Lin, but for Chen Duo as well. Apart from the aforementioned collaborative piece, Chen also composed two other song suites in similar contexts. One is about a banquet at the Fuwentang. ${ }^{125}$ Another, titled "Fuwentang," eulogizes not only the Hall of Literary Abundance but also, and more importantly, its owner, and host for the occasion, Huang Lin. ${ }^{126}$

121) Both shefu 射覆 and cangjiu 藏鬩 were popular games played during banquets and literary gatherings.

122) Yangchun baixue 陽春白雪 is the title of an anthology of Yuan-dynasty sanqu songs.

123) QMSQ, 801-802.

124) JLSS, 3.137b-138a. Huang Lin was an imperial bodyguard in Nanjing, and more importantly, the nephew of an influential eunuch. For biographical details, see Chen Zuolin, Jinling tongzhuan, 14.8b-9a.

125) “Fuwentang yanshang” 富文堂讌賞, in QMSQ, 569-71.

126) $Q M S Q$, 680-82. A note for this song suite in $Q M S Q$ erroneously takes Fuwentang as the name of Chen Duo's studio: see 719, n. 340. 
$\mathrm{Xu}$ Lin was closely acquainted with Huang Lin, who once gave him two hundred taels of gold to build a pavilion in his "Satisfaction Garden" 127 and also sponsored his seventieth birthday celebrations, which involved a hundred singsong girls. ${ }^{128}$ In other words, while $\mathrm{Xu}$ appears to have gained considerable financial independence through his paintings and calligraphy, he may also have enjoyed support from wealthy and powerful figures such as Huang Lin. Xu Shuofang has suggested that this sort of support possibly reflected a mutual interest, as Huang Lin and other officials desired to benefit from the fame of $\mathrm{Xu}$ Lin, very much a celebrity literary figure at the time, while Xu for his part needed the power and wealth of Huang. ${ }^{129}$ Xu's association with local power-holders may be similar to Chen Duo writing for the Duke of Wei, as seen earlier.

$\mathrm{Xu}$ Lin established himself as a major calligrapher and painter, which secured his fame and livelihood, and thus appeared to have nothing to do with the court. We also remember he once claimed that a true scholar needs no official position, portraying himself as a contented figure in the art world. Yet things took a drastic change in 1519. When Emperor Wuzong started his imperial tour of the south, a close attendant presented him with Xu Lin's writings. ${ }^{130}$ Apparently the emperor was quite impressed by Xu's talent. It was even said that he visited Xu's residence twice. ${ }^{131}$ There is a delightful anecdote about the emperor fishing in the pond of Xu's garden and falling into the water, for which the pond was later renamed "Dragon Bathing Pond." ${ }^{32}$ The emperor was so fond of $\mathrm{Xu}$ that he included him as part of his retinue, and $\mathrm{Xu}$

\section{7) JLSS, 4.201b.}

128) Kezuo zhuiyu, 179. We find an almost identical celebration with a hundred singsong girls on the occasion of the sixtieth birthday party of another $q u$ writer, Kang Hai 康海 (1475-1541). See Han Jiegen 韓結根, Kang Hai nianpu 康海年譜 (Shanghai: Fudan daxue chubanshe, 1993), 226.

129) Xu Shuofang, Wan Ming qujia nianpu, vol. 1, 2.

130) Gu Lin, "Yinjun Xu Ziren Lin muzhiming," 115.36a. JLSS states that the close attendant was Zang Xian, but scholars have convincingly shown that this is not possible since Zang was already dead by then. See Wang Gang and Wang Yongkuan, "Shengshi xinsheng yu Zang Xian," 95-96. For an account of Wuzong's tour of the south, see Frederick Mote and Denis Twitchett, eds., Cambridge History of China, vol. 7: The Ming Dynasty, 1368-1644, part 1 (Cambridge: Cambridge Univ. Press, 1988), 430-36.

131) For accounts of Wuzong's visit to Xu's residence, see JLSS, 1.1b-2a and 4.200a-201a.

132) JLSS, 4.200a/b. 
later went with the emperor to Beijing. However, Wuzong passed away shortly after his return to the capital, whereupon $\mathrm{Xu}$ Lin made his way back to Nanjing. His trip to Beijing with the emperor apparently made him even more famous than before.

One source claims that Wuzong once offered $\mathrm{Xu}$ Lin a post in the Court Entertainment Bureau, which Xu begged to decline because the position was associated with professional actors. ${ }^{133} \mathrm{Xu}$ clearly made a distinction between himself and the court performers, and he was perhaps aiming for a proper official position. And yet, one might argue that during the short period when he served the emperor Xu was indeed not much different from the court writers who composed lyrics and songs to please and entertain His Majesty. ${ }^{134}$

\section{Conclusion: Emergence, Remembrance, and Local Tradition}

Although Nanjing had been a center of songs and drama since the beginning of the Ming dynasty, our knowledge of it is largely restricted to what happened in the Ming court, which was very much an anonymous world of $q u$ production for professional entertainment. The first generation of $q u$ writers in Nanjing — men such as Shi Zhong, Chen Duo, and Xu Lin_-represented a different mode of $q u$ writing, located away from the court and emerging in the second half of the fifteenth century. $Q u$ writing was no longer a professional occupation, as with the court performers, it became part and parcel of the writers' cultural and social life.

I have stressed how these authors distanced themselves from the court, but one must not neglect the interactions between $q u$ writing within and outside the court. In fact, the proximity to the world of court entertainment in songs and drama played a considerable role in Nanjing's development as one of the earliest centers of $q u$ writing in the Ming, as in Chen Duo's association with court performers and Xu Lin's role as a court writer for a short period of time.

More generally, the Nanjing literati had many occasions to interact with professional court performers outside the court. It was common

133) $\mathrm{Li} \mathrm{Xu}$ 李詡, Jiéan laoren manbi 戒庵老人漫筆 (Beijing: Zhonghua shuju, 1982), 133.

134) Gu Qiyuan even once called Xu Lin a lingren 伶人 (performer), probably alluding to his role in the emperor's retinue; see Kezuo zhuiyu, 180. 
for court entertainers to be employed for theater and music performances in literati gatherings. ${ }^{135}$ For example, when Gu Lin held banquets in Nanjing, he often employed musicians from the Court Entertainment Bureau. ${ }^{136}$ According to JLSS, during the first five days of the New Year court performers in Nanjing used to visit wealthy families to perform in groups of four or six. ${ }^{137}$ As court performers frequented the residences of the literati to provide entertainment, $q u$ writing also appears to have entered the realm of literati lifestyle. Writing occasional songs at literati gatherings and banquets became more common, as we have seen in the case of the collaborations between Chen Duo and Xu Lin. Such factors encouraged more writers to participate in $q u$ activities and compose songs and drama.

Although Shi Zhong, Chen Duo, and Xu Lin were important figures in the first generation of $q u$ writers, we must bear in mind that $q u$ writing constituted only one part of their cultural activities. All three were also well-known for their talent in poetry, painting, and calligraphy. ${ }^{138} \mathrm{Xu}$ Lin, in particular, gained fame primarily as a painter and calligrapher, the writing of songs and plays being no more than one element in his leisurely pursuits.

Indeed, since $q u$ writing was closely connected to other cultural activities in the lives of such authors, it is important to consider the socio-cultural milieu of Nanjing more generally. We note, for example, that the emergence of the first generation of $q u$ writers coincides with a period during which painting was flourishing in Nanjing. Art historians have established the city as a major painting center in the midMing. By the late fifteenth century, Nanjing was rivaling Suzhou in intellectual and literary activity, and it was probably ahead of Suzhou in terms of the number of important artists active there. ${ }^{139}$ James Cahill has argued for the existence of a group of artists in Nanjing during this period (including Shi Zhong and Xu Lin) who belonged to what he terms the "educated professional" type. These artists were neither

\section{5) Kezuo zhuiyu, 302.}

136) Qian Qianyi, Liechao shiji xiaozhuan 列朝詩集小傳 (Shanghai: Shanghai guji chubanshe, 1983), 339 .

137) This practice stopped around the mid-sixteenth century. See JLSS, 4.245b-246a.

138) For their achievements in poetry, calligraphy and painting, see JLSS, esp. 2.70a-b, 74b, 96b, 101b, 102b, 103b.

139) Cahill, Parting at the Shore, 97-98. 
willing to be regarded as artisans nor able to claim the status of gentryliterati through official rank or family background. ${ }^{140}$ It was perhaps this unique status and social background that created a generation of writers who took up both painting and $q u$ writing as a way of expressing themselves. ${ }^{141}$

We may also place the emergence of this first generation of Nanjing $q u$ writers within the broader context of the revival of sanqu writing. This revival was first seen in the south during the Chenghua and Hongzhi periods, as demonstrated by the works of the Nanjing authors and of other Jiangnan writers as well, such as Wang Pan from Yangzhou or Zhu Yunming and Tang Yin from Suzhou. ${ }^{142}$ The Nanjing writers have often been discussed together with these other Jiangnan writers under the blanket category of "southern writers." These "southern writers" were regarded as mingshi 名士 (“eminent personalities"), meaning free-spirited men of artistic and literary achievement not usually associated with officialdom. Such a characterization differentiates them from $q u$ writers in north China, such as Wang Jiusi, Kang Hai, or Li Kaixian, who were retired or discharged officials. ${ }^{143}$ Yet, to see them in this light is oversimplifying a complex picture, as scholars have shown that as a group the Jiangnan mingshi could hardly be considered uninterested in officialdom and politics. ${ }^{144}$ We have seen that Xu Lin was keen to serve at court (though not in the Court Entertainment Bureau) even after he had established his reputation as an artist.

Binary divisions such as "north vs. south," for example, or "discharged official vs. mingshi," are convenient markers to distinguish between groups of $q u$ writers, but they are inadequate. To understand

\footnotetext{
140) Cahill, "Tang Yin and Wen Zhengming as Artist Types: A Reconsideration," Artibus Asiae 53 (1993): 244.

141) For example, Cahill has suggested that Nanjing painting has a fondness for dramatic effects, while for the artists painting seems to have been itself a performance act. See Cahill, Parting at the Shore, 97.

142) Zhao Yishan, "Mingdai Chenghua Hongzhi nianjian nanqu zhi shengxing yu qu wenxue chuangzuo zhi fuxing” 明代成化、弘治年間南曲之盛行與曲文學創作之復興, Wenyi yanjiu 2005, 12: 95-98.

143) See, e.g., Wang Xingqi 王星琦, Yuan Ming sanqu shilun 元明散曲史論 (Nanjing: Nanjing shifan daxue chubanshe, 1999), 302-41.

144) See e.g. Luo Zongqiang 羅宗強, "Hongzhi Jiajing nianjian Wuzhong shifeng de yige cemian” 弘治、嘉靖年間吳中士風的一個側面, Zhongguo wenhua yanjiu 2002.4: esp. 22-25.
} 
fully the emergence of the $q u$ genre in a particular region, we need to focus on its unique local historical context and study $q u$ writing as a social and cultural activity among communities of writers, as we find it with the first Nanjing generation. Although there may still be disputes over the authorship of some works from this period, the emergence of these authors of songs and drama represented a significant change in the status of $q u$ writing in the mid-Ming.

Here I have focused on the socio-cultural and historical factors that encouraged the emergence of the first generation of $q u$ writers in midMing Nanjing. If we take a step back and reflect on the sources used in the process, it becomes apparent that the list of writers owes much to later scholars attempting to recover the past. While Shi Zhong, Chen Duo, and $\mathrm{Xu}$ Lin did emerge during the late fifteenth century, the fact that their writings and the biographical information on them have been passed down to us depends largely on seventeenth-century sources like JLSS and Kezuo zhuiyu, which are records of life in Nanjing from a later era. ${ }^{145}$ One might also mention the $q u$ anthology, Nanbeigong ciji 南北宮詞紀 (Compilation of songs in the southern and northern styles), which contains a wealth of Nanjing qu writings. Compiled by Chen Suowen 陳所聞 (1526?-after 1605), a native of Nanjing, the Nanbeigong ciji is most detailed in its selection of sanqu both by earlier generations of Nanjing writers and by Chen himself and his friends, such as Huang Zuru 黃祖儒 (zi Shuchu 叔初, n.d.), Sheng Min'geng 盛敏耕 (1546-1598), or Du Dacheng 杜大成 (ca.1549-after 1619). ${ }^{146}$ For example, all of Xu Lin's extant songs are preserved thanks to it.

In other words, our understanding of the first-generation $q u$ writers in Nanjing is highly dependent on what one might call "local" publications. Such publications feature a conscious act of remembrance of past splendor and glory by local writers. Local pride was displayed and achieved through recording the legacy of the city. In her recent study,

145) On the significance of JLSS and Kezuo zhuiyu as records of contemporary conversations among urban elites about the city of Nanjing, see Si-yen Fei, Negotiating Urban Space: Urbanization and Late Ming Nanjing (Cambridge, Mass.: Harvard Univ. Asia Center, 2009), chapter four.

146) See Nanbeigong ciji, ed. Zhao Jinshen (1959; rpt. Taipei: Xuehai chubanshe, 1971), passim. See also QMSQ, 2478-590 (Chen Suowen), 3181-82 (Sheng Min'geng), 3237-47 (Huang Zuru), and 3414-46 (Du Dacheng). 
Si-yen Fei has argued that the authors of such works as JLSS and Kezuo zhuiyu considered themselves curators of Nanjing culture, and that their efforts in collecting Nanjing "trivia" facilitated a shared sense of "Nanjing-ness" for late-Ming literati. ${ }^{147}$ In the case of $q u$ writing, it is interesting to consider how such an effort in recording earlier generations of Nanjing writers with their songs and dramatic works might be perceived as an attempt to claim authority for a "trivial" and marginal subject like $q u$. The long list of twenty $q u$ writers in JLSS, which was subsequently updated in Kezuo zhuiyu, built a "lineage" of Nanjing writers from early to late Ming. And the anthology compiled by Chen Suowen functioned as an archive for these Nanjing sanqu songs. In this way a local tradition of $q u$ writing in Nanjing was gradually constructed.

From the viewpoint of later seventeenth-century writers, the first generation belonged to a golden age that had been lost. This sentiment was clearly spelled out by Gu Qiyuan when he lamented that, although Chen Suowen's talent in $q u$ writing was not inferior to that of Chen Duo or Xu Lin, he did not have the good fortune to enjoy the great age during which Chen and Xu were respected for their skills in $q u$ writing. ${ }^{148}$ This act of remembrance even continued into the twentieth century, as exemplified by Lu Qian, a pioneer scholar in the field of $q u$ studies and a native of Nanjing as well, who around 1929 updated and expanded the list of Nanjing $q u$ writers. ${ }^{149}$ The following lines by Lu well encapsulate the kind of sentiment experienced by later Nanjing readers when they encountered works by the first-generation $q u$ writers:

To think of those days in the past, the magnificence of the tradition of song writing in our hometown was first in the empire. Now it has lost its glamor and reputation. As one reads Dasheng's [Chen Duo] songs, how can one not sigh over it? 遙想當日, 吾鄉詞風之盛, 甲於天下。今也暗然無聞。讀大聲之樂府, 又 不能無嘆矣。150

147) Si-yen Fei, Negotiating Urban Space: Urbanization and Late Ming Nanjing, 209-11.

148) Kezuo zhuiyu, 180.

149) Lu Qian, Lunqu jueju, in Lu Qian quxue sizhong, 250-51. The last of his forty songs in this volume states that he was then twenty-four. Thus, we know that these songs were written around 1929.

150) Ibid., 249. 
The first generation of Nanjing $q u$ writers emerged from the anonymous context of court entertainment and established their names and reputation in the second half of the fifteenth century. Although they may occasionally have been forgotten, they are now known to us. This they owe to later generations of writers and critics, mostly natives of Nanjing, who fervently recorded these early figures as a means to uphold the local tradition of $q u$ writing in Nanjing. 